\title{
PEMIKIRAN HERMENEUTIKA AMINA WADUD MUHSIN
}

\author{
Eka Prasetiawati \\ ekaprasetiawati@iaimmetro.ac.id \\ Dosen IAIM Metro Lampung
}

\begin{abstract}
Abstrak:
Perkembangan ilmu pengetahuan terjadi pada semua bidang ilmu. Tak terkecuali bidang ilmu-ilmu al-Qur'an. Di Barat lahir seorang tokoh perempuan yang menghebohkan dunia Islam pada saat itu, bahkan hingga saat ini. Namanya adalah Amina Wadud Muhsin. Ia seorang Profesor Islamic Studies yang pernah menjadi imam shalat Jum'at. Dalam jum'atan tersebut, imamnya perempuan, khatibnya perempuan dan barisan makmumnya bercampur aduk antara laki-laki dan perempuan. Sejak 1400 tahun lebih Islam di sebarkan oleh Nabi Muhammad, baru Amina Wadud-lah orang yang berani menjadi imam shalat Jum'at. Amina Wadud melakukan hal tersebut tentu bukan asal-asalan, namun juga memiliki dasar. Dasar yang di pakai olehnya adalah hermeneutika tauhid. Dalam hal ibadah, seseorang tidak boleh di halangi hanya karena jenis kemanin, asalkan bertauhid, ia boleh beribadah. Selain itu, factor kondisi geografis dimana Amina Wadud tinggal juga menjadi alasan utmanya untuk melakukan hal itu.
\end{abstract}

Kata kunci: Amina Wadud, bermeneutika.

\section{A. Latar Belakang}

Sudah maklum di ketahui bahwa Hermeneutika adalah sebuah metode yang di tawarkan oleh Barat untuk mengkaji Injil (Alkitab). Penggunaan ini sangat tepat, sebab teks Injil sama sekali tidak mengikat untuk di aplikasikan secara literal. Hal ini dapat dilihat dari beberapa aspek. Pertama, Jika di tinjau dari sisi sejarah, maka kita akan menemukan bahwa keempat Injil kanonik, yaitu Matius, Markus, Lukas dan Yohanes penulisannya tidak didektekan oleh 
Yesus dan jauh setelah Yesus, yakni tahun 65-100 M. ${ }^{1}$ Bukan itu saja persoalannya, pada tahun 325 M. diadakan konsili ${ }^{2}$ di Nikea yang memutuskan bahwa, keempat Injil tersebut yang sah, semantara yang lain dinyatakan apokrip (dilarang untuk di baca). Yang menarik dalam proses seleksi Injil ini adalah, pada saat konsili itu berlangsung, ada 113 Injil dan semua versi Injil tersebut diletakkan secara acak diatas meja jamuan suci didalam gereja, serta di kunci rapat-rapat. Entah dengan apa, keesokan harinya keempat Inil tersebut sudah ada diatas meja, sementara yang lain di bawah. ${ }^{3}$ Keberagaman Injil tersebut ternyata memang di akui oleh naskah Injil itu sendiri.

Aku heran, bahwa kamu begitu lekas berbalik dari pada dia, yang oleh kasih karunia Kristus telah memanggil kamu, dan mengikuti semua Injil lain, yang sebenarnya bukan Injil. Hanya orang yang mengacaukan kamu dan yang bermaksud untuk memutarbalikkan Injil Yesus. $^{4}$

Poin penting lain dalam menerapkan hermeneutika terhadap Injil adalah karena Injil selain bermasalah dalam segi sejarah juga bermasalah dari sisi substansi, ${ }^{5}$ revisi, ${ }^{6}$ dan versi. ${ }^{7}$ Dan yang tidak

${ }^{1}$ Hamid Qadri, Awan Gelap dalam Keimanan Kristen: Perjalanan Sejarah Kepercayaan Kristen, Pengaruh Mitologi Kuna dan Filsafat, terj. Masyhur Abadi. Surabaya: Pustaka Da’i, 2004, 163-176. Yang mengutip dari sumber-sumber Kristen: J. T. Sunderland, The Bible - its Growth and Origin, 125. Hastings, The Encyclopedia of Religion and Ethnics.

${ }^{2}$ Konsili adalah konvrensi yang membahas tentang masalah akidah.

${ }^{3}$ Hamid, 187. Yang menutip dari H. P. Blavatasky, Isis Unveiled, vol. vii, h. 251.

${ }^{4}$ Lembaga Alkitab Indonesia, Perjanjian Baru, Mazmur dan Amsal. Jakarta: Lembaga Alkitab Indonesia, 2010, 287. /Galatia 1: 6-8.

5 Ahmad Deedat, The Choice. Jakarta: Pustaka al-Kautsar, 1999, 341-343. Majalah Awake yang di terbitkan pada tanggal 8 September 1987, volume xxxviii, oleh Sekte Kristen Yehovah menuliskan judul besar dalam halaman depan "50.000 Kesalaban Injil". Itu berarti jika seseorang mengimani Injil bulat-bulat, maka ia akan terjebak kedalam kesalahan-kesalahan yang nyata. Poin ini juga diperkuat oleh kitab yang ditulis oleh Syaikh Rahmatullāh al-Kirāni, Iẓ̌ār al-Ḥăq. Molyadi Samuel, Dokumen Kepalsuan Alkitab (Surabaya: Victory Press, 2002), serta ada pula catatan tereahir dari buku mantan biarawati Irena Handono, Islam Dihujat (Kudus: Bima Rodheta, 2004).

${ }^{6}$ Sebut saja misalnya RSV (Reviced Standart Version), CEV (Contemporery English Version), KJV (King James Version), yang mana masing-masing revisi tersebut 
kalah menarik adalah hasil dari penelitian 76 Doktor Teologi Kristen yang terfokus pada kelima Injil kanonik ditambah lagi dengan Injil Thomas, dan penelitian tersebut dilaksanakan selama enam tahun, ${ }^{8}$ sementara hasilnya adalah sangat mengejutkan, Eighty two percent of the words ascribed to Yesus in the Gospels were not actually spoken by him. 'A Atau delapan puluh dua persen ayat yang ada dalam lima Injil, itu tidak dikatakan oleh Yesus, alias palsu.

Itulah gambaran penting mengapa hermeneutika sangat tepat ketika digunakan oleh Kristen, sebab ketentuan atau hukum-hukum yang ada didalam Injil tidaklah mengikat. Dan oleh sebab itu, penerapan kontekstualisasi dalam tubuh umat Kristen tidak mengherankan, sebab dengan tidak terikat oleh teks-teks Bibel, mereka dengan leluasa menafsirkan kitab suci sesuai dengan 'selera pasar' dimana ia berada, atau istilah halus yang digunakan dalam hermeneutika adalah 'kontekstualisasi'.

Yang menjadi janggal adalah ketika metode dari Bibel ini diaplikasikan kedalam al-Qur'an perbedaan kevalidan data dan sejarah. Untuk itu wajar, jika memang umat Islam menilainya berbeda-beda, ada yang menolak ataupun menerima. Dalam hal ini, penulis akan mencoba memaparkan tentang hermeneutika yang digagas oleh seorang feminis Muslim kontroverisial di zaman sekarang, yakni Amina Wadud Muhsin.

B. Biografi Amina Wadud Muhsin

Menurut data yang ditulis oleh Saiful Amin Ghafur yang menutip pendapat dari Charlez Khuzman, dalam karyanya Liberal Islam, ia adalah seorang wanita kelahiran Amerika pada tahun 1952

memuat data-data yang berbeda, dengan cara memodivikasi dan mengurangi ayat-ayat yang dianggap palsu.

7 Injil Katolik memuat kitab Tobit, Yudit, I Makabe, II Makabe, Kebijaksanaan Salomo Sirakh dan Barukh. Sementara kitab-kitab tersebut tidak dipakai oleh Protestan. Lihat, Molyadi Samuel, Dokumen Kepalsuan Alkitab. Surabaya: Victory Press 2002, 13-14.

${ }^{8}$ Robert Funk, Roy W. Hoover and The Jesus Seminar, The Five Gospels. What Did Jesus Really Say? Harper San Fransisco: 1997, ix.

${ }^{9}$ Robert Funk, ... 5. 
M. ${ }^{10}$ Sahiron Syamsudin juga mencatat, bahwa ayahnya adalah seorang pendeta yang taat. ${ }^{11}$ Dalam perjalan hidupnya di tengahtengah keluarga Kristen, Amina Wadud ahirnya mendapatkan hidayah dari Allah sehingga ia tertarik kepada Islam, karena konsep keadilan dalam Islam. Setelah tertarik kepada Islam, ahirnya pada usia ke-20 tahun, tepatnya pada tahun 1972, ia meneguhkan hati untuk berpindah keyakinan kepada Islam dengan mengucapkan dua kalimat syahadat, sehingga hari bersejarah itu ia sebut dengan Thanksgiving day. Puncak karir intelektual Amina Wadud dapat dilihat tentang pencapaiannya menjadi guru besar (profesor) Islamic Studies di Commonwelth University, di Richmond Virginia Amerika Serikat. ${ }^{12}$

C. Karya

Sejauh yang penulis ketahui, beberapa karya yang ditulis oleh Amina Wadud Muhsin adalah Qur'an and Woman: Rereading the Sacred Text from a Women's Perspective (Kuala Lumpur, Fajar bakti, 1992); Inside the Gender Jihad, Women's Reform in Islam (England: Oneword Publication, 2008); Liberal Islam (New York: Oxford University Press, 1998).

D. Pemikiran

Sebelum kita mengkaji tentang pemikiran Amina Wadud, terlebih dahulu akan penulis kemukakan tentang alasannya, mengapa ia harus menjadi seorang reformis-feminis. Amina melihat, bahwa keterpurukan kaum perempuan Islam itu disebabkan oleh budaya patriarki yang diusung oleh kaum pria. Hal ini dapat dilacak dengan adanya karya-karya yang di tulis oleh kaum pria yang terkesan membela kelompok mereka dan memojokkan peran-serta kaum

\footnotetext{
10 Saiful Anwar Ghafur, Profil Para Mufasir al-Qur'an. Yogyakarta: Pustaka Insan Madani, 2008, 234.

11 Sahiron Syamsudin, Hemeneutika al-Qur'an dan Hadis. Sleman Yogyakarta: Elsaq Press, 2010, 178-179.

${ }^{12}$ Ibid, 178-179. Lihat juga pada, Adian Husaini, Hegemoni Kristen-Barat dalam Studi Islam di Perguruan Tinggi. Jakarta: Gema Insani Press, 2006, 252.
} 
wanita. Oleh sebab itu, ia memberanikan langkah untuk memperjuangkan kaum wanita agar menjadi setara dengan pria. ${ }^{13}$

1. Mencurigai karya mufasir klasik

Yang menjadi ciri khas dari beberapa pemikir yang notbene dari Barat adalah gagasannya tentang para mufasir klasik yang dinilai kuna dan bahkan tidak relevan lagi di era sekarang. Itu artinya pemikiran mereka sudah usang bahkan disalahkan oleh para pemikir modern, termasuk Amina Wadud Muhsin. Dalam hal ini proses pertama yang dilakukan oleh Amina Wadud demi tercapainya gagasan yang ia tawarkan tentang feminisme adalah mencurigai para ulama klasik yang dinilainya bias gender. Hal ini wajar karena memang para mufasir klasik adalah para kaum pria dan bisa dipastikan mereka akan menggunakan kesempatan itu untuk menguatkan penafsirannya dan terkesan memarjinalkan kaum wanita. Langkah pertama yang ditempuh oleh Amina Wadud adalah dengan cara memberikan label terlebih dahulu kepada para mufasir klasik, bahwa mereka 'melakukan kesalahan' dalam memahami teks-teks al-Qur'an, sehingga apa yang ditulisnya menjadi berat sebelah.

2. Prior text

Secara singkat dapat kita katakan bahwa, gagasan pemikiran Amina Wadud salah satunya adalah tentang prior text. Kata prior adalah bahasa Inggris yang memiliki arti dahulu, sebelumnya. Sementara text adalah tulisan. Jadi, gabungan dari dua kata ini dapat dipahami sebagai 'teks-teks yang terdahulu'. Dalam pandangan penulis, teks terdahulu yang dimaksud adalah adanya sebuah pengaruh yang panjang dan kuat terhadap umat Islam sehingga mereka ikut-ikutan dengan faham yang di usung olek para mufasir klasik yang notabene adalah kaum pria yang cenderung membela diri mereka sendiri. jadi pengaruh bacaan yang ditulis oleh para mufasir yang 'bias gender' ini menjadi

13 Sahiron Samsudin, Hermeneutika al-Qur'an dan Hadis. Sleman Yogyakarta: Elsaq, 2010, 177. 
konsumsi mereka dan akibatnya adalah mereka ikut terjebak kedalam sikap yang sama, yakni sama-sama menganggap wanita tidak sejajar dengan pria. Sederhananya, prior text adalah persepsi, keadaan, dan latar belakang orang yang menafsirkan al-Qur'an.

3. Menawarkan metode baru "Hermeneutika Tauhid" dan konsep takwa

Menurut Amina, teks al-Qur'an sudah jelas manyatakan kesetaraan antara pria dan wanita. Hal ini termaktub dalam alQur'an surat al-Hujurāt [49]: 13 sebagai berikut:

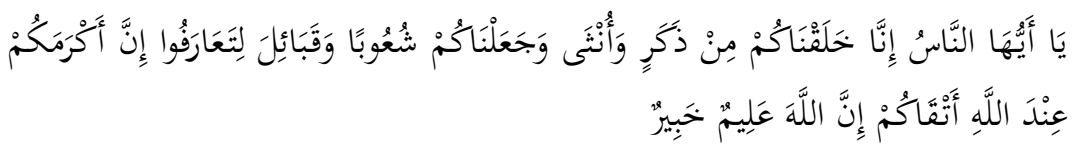

Hai manusia, sesunggubnya Kami menciptakan kamu dari seorang lakilaki dan seorang perempuan dan menjadikan kamu berbangsa - bangsa dan bersuku-suku supaya kamu saling kenal-mengenal. Sesunggubnya orang yang paling mulia diantara kamu disisi Allah ialah orang yang paling taqwa diantara kamu. Sesunggubnya Allah Maha Mengetahui lagi Maha Mengenal.

Penegasan al-Qur'an ini menjadi salah satu kunci bagi Amina Wadud untuk mengatakan, bahwa didalam al-Qur'an priawanita itu sama-sama. oleh sebab itu, sah-sah saja bagi wanita apabila ia tampil menjadi pemimpin diberbagai bidang, baik agama maupun negara.

Selain nash al-Qur'an diatas, salah satu kisah dalam alQur'an juga dijadikan pedoman bahwa, dalam Islam juga ada wanita yang eksis sebagai pemimpin. Kisah ratu Bilqis yang memiliki singgasana agung juga diceritakan oleh al-Qur'an. ditambah lagi dengan adanya hadis yang diriwayatkan oleh Ibnu Majjah yang mengatakan bahwa Ummi Waraqah diperintahkan oleh Nabi untuk menjadi imam bagi keluarganya. ${ }^{14}$ Dengan

${ }^{14}$ Sahiron, ... 178. 
demikian, yang menjadi tolak ukur dalam Islam bukanlah dari sisi jenis kelamin, akan tetapi yang menjadi ukuran adalah takwa. Oleh sebab itu, dengan ukuran takwa inilah Amina Wadud menawarkan suatu konsep baru untuk menyama-ratakan antara pria-wanita dengan satu konsep sederhana, yakni 'Tauhid.' Artinya, dengan memiliki keimanan yang sama kepada Allah swt. maka seseorang telah memiliki legitimasi untuk menjadi pemimpin, tanpa harus memperhitungkan apa jenis kelaminnya!.

4. Tentang penciptaan wanita

Surat al-Nisā' ayat pertama menyatakan sebagai berikut:

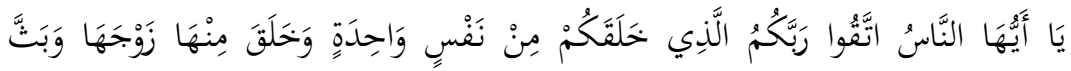

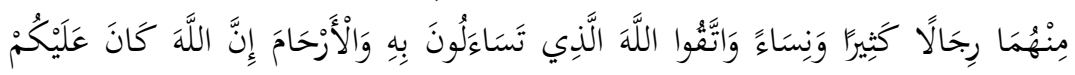

رَقِيبًا

Hai sekalian manusia, bertakwalah kepada Tuhan-mu yang telah menciptakan kamu dari seorang diri, dan dari padanya Allah menciptakan isterinya; dan dari pada keduanya Allah memperkembang biakekan lakilaki dan perempuan yang banyak. dan bertakwalah kepada Allah yang dengan (mempergunakan) nama-Nya kamu saling meminta satu sama lain, dan (peliharalah) bubungan silaturrabim. Sesunggubnya Allah selalu menjaga dan Mengawasi kamu.

Amina Wadud tidak jauh berbeda dengan para tokoh hermeneutika lainnya yang mana fokus kajiannya hanya itu-itu saja, yakni tentang gender, pembolehan hukum yang dulunya haram, dan sebaliknya. Dalam penciptaan wanita misalnya, ia tidak terima jika wanita diciptakan dari tulang rusuk Adam. Sementara, Adam diciptakan oleh Tuhan dengan wujud yang sempurna. Hal inilah yang dipandang oleh Amina Wadud sebagai hasil dari interpretasi yang bisa gender.

Kata kunci dalam ayat diatas yang menjadi titik tekan Amina Wadud adalah pada kata nafs wähidah, min dan zauj. Dalam pandangannya, istilah nafs itu menunjuk kepada semua 
asal manusia secara umum, dan bukan berarti feminim atau maskulin. Menurutnya, kisah tersebut adalah menunjukkan asal usul kejadian manusia versi al-Qur'an. Namun biasanya kata nafs tersebut oleh para mufasir dimaknai sebagai Adam. Padahal sebenarnya tidak ada kejelasan dalam al-Qur'an mengenai kata nafs, apakah itu Adam atau Hawa?. Oleh sebab itu titik poin dalam masalah ini adalah kata nafs tersebut adalah bentuk mu'annath, namun mengapa bagi para mufasir klasik dimaknai sebagai pria?.

Sementara itu, para ulama menafsirkan kata nafs wāhidah dengan Adam, sedangkan kata minha ditafsirkan dengan tulang rusuk bagian kiri Adam, yang mana pemahaman tersebut diusung dari beberapa hadis yang tercantum didalam kitab sharh Ibnu Hajar al-Athqalāni, Fatḥ al-Bäri li al-Sharḥ Bukhäri, Imam Muslim dengan Sharb Al-Nawawi. Yang mana keduanya sama-sama memberikan suatu pemahaman bahwa nafs wähidah adalah Adam. ${ }^{15}$ Oleh karenanya, apa yang disampaikan oleh para pensharh hadis tersebut termasuk kedalam golongan mujtahid, dan oleh sebab itu wajar jika berbeda dengan mujtahid yang lain. menolak hasil ijtihad itu berbeda dengan al-Qur'an dan Amina Wadud tidak menolak al-Qur'an, akan tetapi menolak hasil pemahaman seseorang tentang al-Qur'an, terutama yang menyangkut masalah gender. Selain itu, para mufasir tidak menjelaskan latar belakang hadis tersebut sebagai dasar penafsiran ayat diatas.

Selain itu, kata zauj dalam bahasa Arab itu memiliki arti yang netral pula. Yakni bisa untuk pria maupun wanita. Jadi tidak terpaku kepada satu arti bahwa zauj yang dimaksud dalam ayat ini adalah seorang wanita. Atau istilah lain dalam bahasa kita mungkin disebut dengan pasangan. Jadi kata tersebut tidak

${ }^{15}$ Sahiron, ... 194. 
terpaku pada satu pemahaman pria saja, atau wanita saja, keduaduanya bisa dimasukkan.

Kata lain yang menjadi perhatian Amina Wadud adalah lafad min. Dalam bahasa Arab, kata min itu bukan hanya memiliki arti 'dari' yang menunjukkan bagian sesuatu. Akan tetapi min juga bisa memiliki arti 'sama' atau semacam, yang mana dalam bahasa Arab disebut sebagai min jinsiyyah. Dalam hal ini mayoritas mufasir menuliskan min dengan arti dari, bukan min yang dimaknai 'sejenis'. ${ }^{16}$ Inilah yang disebut oleh Amina Wadud sebagai 'penyimpangan penafsiran' karena didominasi oleh kaum pria.

5. Tentang kepemimpinan wanita

6.

Pada bab sebelumnya penulis telah menjelaskan tentang prihal kepemimpinan wanita dalam masalah ibadah, yakni dengan hermeneutika tauhid seseorang tidak ada bedanya lagi di hadapan Tuhan. Jika ia adalah orang yang beriman, maka porsinya sama dihadapan Tuhan, dan ukurannya bukanlah jenis kelamin, akan tetapi takwa. Dalam masalah ini, penulis akan menjelaskan tentang argumentasi Amina Wadud yang menyinggung al-Qur'an, bahwa wanita itu boleh menjadi pemimpin. Hal ini tertera dalam surat al-Naml [27]: 22-23 sebagai berikut:

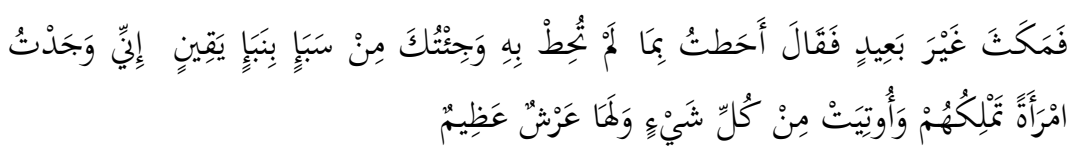

Maka tidak lama kemudian (datanglah bud-hud), lalu ia berkata: "Aku telah mengetahui sesuatu yang kamu belum mengetahuinya; dan kubawa kepadamu dari negeri Saba, suatu berita penting yang diyakini. Sesunggubnya Aku menjumpai seorang wanita yang memerintah mereka, dan dia dianugerahi segala sesuatu serta mempunyai singgasana yang besar.

${ }^{16}$ Sahiron, ... 195. 
7. Tentang nushuz

Amina Wadud memang orang yang sangat teliti dalam melakukan kajian, dan salah satu poin penting yang dijadikan argumentasinya untuk membela kuam wanita adalah pada saat ia menafsirkan ayat tentang nusu\%. Ayat yang menjelaskan hal tersebut adalah sebagai berikut.

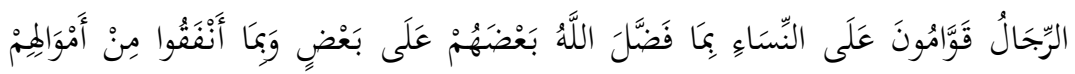

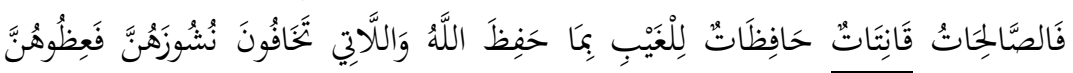

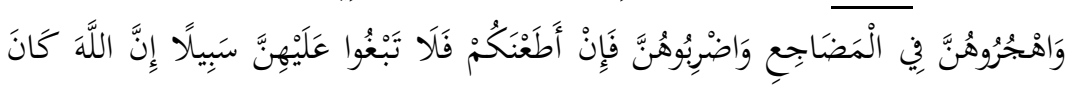
عَلِيَّا كَبِيرًا

Kaum laki-laki itu adalah pemimpin bagi kaum wanita, oleh karena Allah telah melebibkan sebabagian mereka (laki-laki) atas sebabagian yang lain (wanita), dan karena mereka (laki-laki) telah menafkabkan sebagian dari harta mereka. sebab itu maka wanita yang saleh, ialah yang taat kepada Allah lagi memelihara diri ketika suaminya tidak ada, oleh karena Allah telah memelibara (mereka). wanita-wanita yang kamu khawatirkan nusyuznya, maka nasehatilah mereka dan pisabkanlah mereka di tempat tidur mereka, dan pukullah mereka. Kemudian jika mereka mentaatimu, maka janganlah kamu mencari-cari jalan untuk menyusabkannya. Sesungguhnya Allah Maha Tinggi lagi Maha Besar.

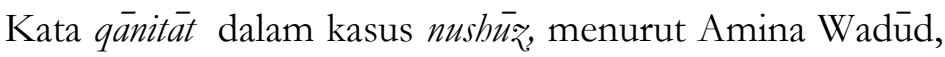
kata ini bermaksud baik, yang menggambarkan suatu karakteristik atau personalitas kaum yang beriman kepada Allah. Kata ini berlaku kepada laki-laki QS al-Baqarah [2]: 238; Ali Imrān [3]: 17, maupun bagi perempuan al-Nisā' [4]: 34, al-Aḥāb [33]: 34. Kombinasi dari ayat-ayat ini menunjukkan 'taat adalah menganjurkan respon pribadi, bukan mengikuti faktor eksternal.' Karena ayat qāität adalah berlaku bagi laki-laki dan perempuan, maka kata tersebut tidak boleh serta-merta disandarkan kepada perempuan saja. dalam hal ini Amina Wadud mengutip pendapat 
Sayydi Qutb, yakni nushü dirtikan sebagai 'keadaan kalut dalam keluarga.'

Dalam al-Nisā' [4]: 34 ini, jika ada permasalahan, alQur'an menekankan kepada pasangan suami istri agar tetap harmonis melalui empat tahap. Pertama, memperingatkan dengan ucapan. Kedua, melalui penengah. Ketiga, pisah ranjang, dan. Keempat, adalah dengan pemukulan. ${ }^{17}$ Jadi pesan utama yang ditekankan oleh al-Qur'an adalah keharmonisan, bukan melakukan tindakan yang semena-mena yang berujung kepada kekerasan dalam rumah tangga.

Sementara itu, menurut Abdul Mustaqim, kata fadribūbun itu tidaklah harus dimaknai dengan memukul. Dalam kamus Lisan Arab, kata tersebut juga bisa berarti 'berpalinglah kamu darinya'. Oleh sebab itu, pemaknaan dengan memukul itu akan membahayakan bagi perempuan. Dan tafsir inilah yang dapat meminimalisir terjadinya kekerasan dalam rumah tangga. ${ }^{18}$

E. Aksi

Pada hari Jum'at tanggal 18 Maret 2005, ada sebuah peristiwa yang menghebohkan dunia Islam. Yakni, Amina Wadud menjadi imam shalat Jum'at di sebuah Gereja Katedral di Sundram Tagore Gallery 137 Green Street, New York Amerika. Wadud menjadi imam sekaligus khatib dalam shalat Jum'at yang diikuti sekitar 100 jamaah laki-laki dan perempuan yang bercampuran barisannya. Mu'azinnya juga perempuan dengan tanpa megenakan kerudung. ${ }^{19}$

17 Sahiron, ...184.

18 Abdul Mustaqim, Dinamika Sejarah Tafsir al-Qur'an: Studi Aliran-aliran Tafsir dari Periode Klasik, Pertengahan, hingga Modern-Kontemporer. Yogyakarta: Adab Press, 2012, 1920.

19 Adian Husaini, Hegemoni Kristen Barat dalam Studi Islam di Perguruan Tinggi. Jakarta: Gema Insani Press, 2006, 252. 
Apa yang dilakukan oleh Amina Wadud ini benar-benar rekor di dunia Islam, sebab, sejak 14 abad lebih, belum ada satupun wanita dalam Islam yang berani untuk menjadi imam dalam shalat Jum'at. Diakui atau tidak, hal iu merupakan suatu keberanian yang ada pada diri Amina Wadud Muhsin yang percaya diri sebagai seorang mujtahid.

\section{F. Analisa}

\section{Kelemahan}

Jika pemikiran Amina Wadud tersbut benar, maka ia hanya memberikan penafsirn satu dari ribuan ayat yang ada dalam al-Qur'an, dan oleh sebab itu, bukan levelnya apabila ia mengkritik para mufasir klasik yang memiliki karya lebih brilian dan selaras dengan asas Islam.

Pemikirannya tentang prior text, yang katanya adalah imbas dari buah pemikiran para mufasir laki-laki klasik, maka dalam hal ini, justru Amina Wadud juga terjebak dalam teorinya sendiri. Jika para umat Islam pada saat ini terjebak dengan bacaan yang mereka konsumsi dan dinilai sebagai bias gender, maka dalam hal ini Amina Wadud juga terkena prior text terhadap konsep hermeneutika yang dibangun oleh Fazlur Rahman, dan hal itu diakuiya sendiri. Jadi jika dikatakan saling taqlid, umat Islam pada umunya taqlid kepada para ulama klasik, sementara Amina Wadud taqlid kepada Fazlur Rahman.

2. Kelebihan

Memberikan sumbangsih terhadapat para kaum wanita, terutama untuk meminimalisir kekerasan dalam rumah tangga khususnya dalam masalah nusbuz - dan memompa semangat bagi kaum wanita untuk unjuk kebolehan, bahwa ia adalah kaum yang bisa bangkit dan mengimbangi kaum pria dari berbagai aspek, baik politik maupun bidang yang lain.

\section{Kritik}

a. Hadis tentang imam shalat sebagai argumen Amina Wadud adalah d̦a'if 


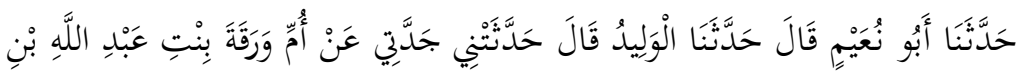

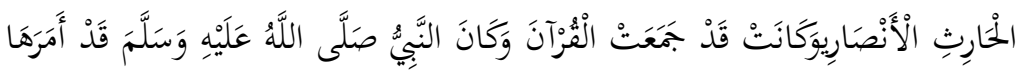

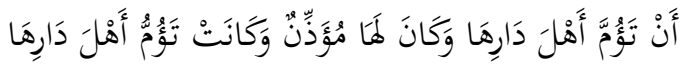

Telah menceritakan kepada kami Abu Nu'aim berkata, telah menceritakan kepada kami al-Walid berkata, telah menceritakan kepadaku neneke.eu dari Ummu Waraqah binti Abdullāh bin al-Harits al-Anshari dan ia pernah ikut mengumpulkan Al-Qur'an, sedangkan Nabi saw. telah memerintabkan kepadanya untuk memimpin shalat keluarganya, ia mempunyai tukang adzan dan ia menjadi imam di rumahnya."

Perawi 1. Nama Lengkap : Al Fạl bin Dukain bin Hammad bin Zuhair, termasuk kalangan 'Tảbi' al-Tăbi'in tua, kuniyahnya Abu Nu'aim, negeri semasa hidup di Kufah dan wafat pada tahun $218 \mathrm{H}$. Menurut al-Nasa'i Thiqqah al-Ma'mun.

Perawi 2. Nama Lengkap : Al Walid bin 'Abdullah bin Jami', Tabi'in kalangan biasa. Kuniyahnya tidak jelas, negeri semasa hidup di Kufah, tahun wafat tidak jelass dan Menurut Abu Dawud, Ahmad bin Hambal dan Ibnu Zur'ah, laisa bibi al$b a$ 's.

Perawi ke-3. Nama Lengkap : Laila binti Malik, Kalangan : Tabi'in kalangan pertengahan, kuniyahnya tidak ada, negeri semasa hidup tidak ditemukan serta tahun wafatnya juga tidak di temukan. Tiada komentar ulama, hanya kata maqbul, itupun tidak ada nama yang menyatakan.

Perawi ke-4. Nama Lengkap : Ummu Waraqah binti 'Abdullah bin Al Harits Kalangan : Shahabiyah Kuniyah : Ummu Waraqah Negeri semasa hidup di Madinah Wafat : ....? Sahabat .

b. Hadis yang di kritik oleh Amina Wadud, yang katanya 'tidak memiliki sebab khusus', ternyata shahih. 


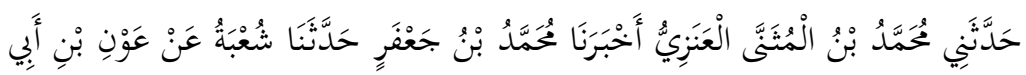

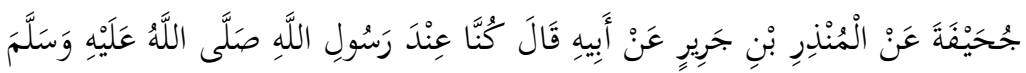

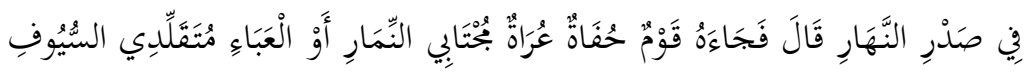

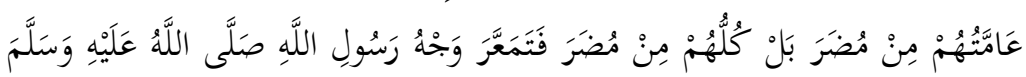

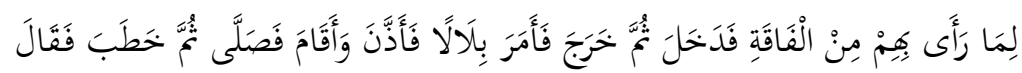

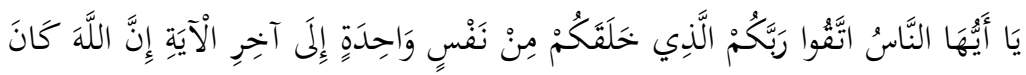

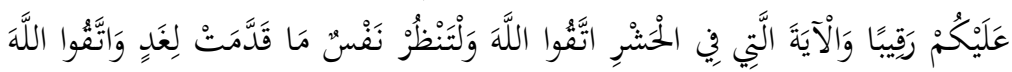

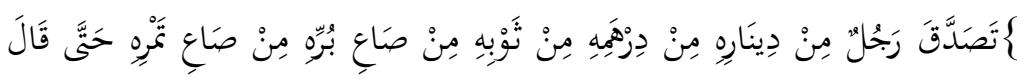

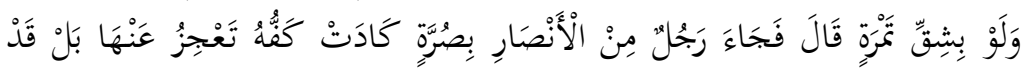

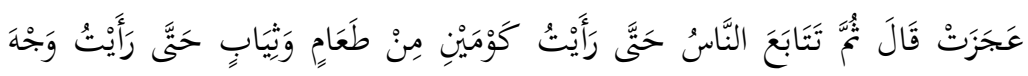

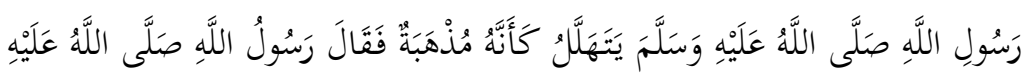

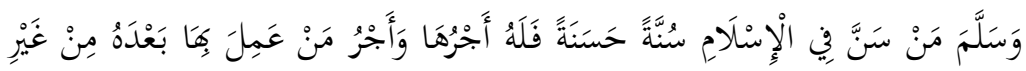

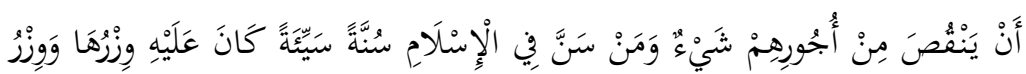

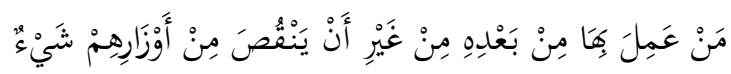
Telah menceritakan kepadaku Muhammad bin Al Mutsanna Al Anazi telah mengabarkan kepada kami Muhammad bin Ja'far Telah menceritakan kepada kami Syu'bah dari Aun bin Abu Juhaifah dari Al Mundzir bin Jarir dari Jarir ia berkata; Pada suatu pagi, ketika kami berada dekat Rasulullah shallallahu 'alaibi wasallam, tiba-tiba datang segerombongan orang tanpa sepatu, dan berpaiakan selembar kain yang diselimutkan ke badan mereka sambil menyandang pedang. Kebanyakan mereka, mungkin selurubnya berasal dari suku Mudlar. Ketika melihat mereka, wajah Rasulullah shallallabu 'alaihi wasallam terharu lantaran kemiskinan mereka. Beliau masuk ke rumabnya dan keluar lagi. Maka disurubnya Bilal adzan dan iqamah, sesudab itu beliau shalat. Sesudah shalat, beliau berpidato. Beliau membacakan firman Allah: "Hai sekalian manusia, bertakwalah kepada Tuhan-mu 
yang Telah menciptakan kamu dari seorang diri..., " hingga akhir ayat, "Sesunggubnya Allab selalu mengawasi kalian." kemudian ayat yang terdapat dalam surat Al Hasyr: "Hai orang-orang yang beriman, bertakwalah kepada Allah dan hendaklah setiap diri memperhatikan apa yang Telah diperbuatnya untuk hari esok (akbirat); dan bertakwalah kepada Allah..., " Mendengar khutbah Nabi shallallabu 'alaibi wasallam itu, serta merta seorang laki-laki menyedekahkan dinar dan dirhamnya, pakaiannya, satu sha' gandum, satu sha' kurma sehingga Nabi shallallahu 'alaibi wasallam bersabda: "Meskipun hanya dengan setengah biji kurma." Maka datang pula seorang laki-laki Anshar membawa sekantong yang hampir tak tergenggam oleh tangannya, babkan tidak terangkat. Demikianlah, akbirnya orangorang lain pun mengikuti pula memberikan sedekah mereka, sebingga kelihatan olehku sudah terkumpul dua tumpuk makanan dan pakaian, sehingga kelihatan olebku wajah Rasulullah shallallahu 'alaibi wasallam berubah menjadi bersinar bagaikan emas. Maka Rasulullah shallallabu 'alaihi wasallam pun bersabda: "Barangsiapa yang memulai mengerjakan perbuatan baik dalam Islam, maka dia akan memperoleh pabalanya dan pabala orang yang mencontob perbuatan itu, tanpa mengurangi pahala mereka sedikitpun. Dan barangsiapa yang memulai kebiasaan buruk, maka dia akan mendapatkan dosanya, dan dosa orang yang mengikutinya dengan tanpa mengurangi dosa mereka sedikit pun." 20

c. Mencurigai ulama klasik karena bias gender

Apa yang diungkapkan oleh Amina Wadud, bahwa penafsiran nafs wāhidah yang diartikan sebagai Adam, ditentang olehnya, sebab kata tersebut tidaklah menunjukkan laki-laki, apalagi ada sandaran wāhidah, bukan wāhid. Ditambah lagi dengan kata zauj pada lafad setelahnya itu juga tidaklah pasti merujuk pada seorang wanita, tepatnya kata tersebut netral, bisa pria maupun wanita. Dan jika dikembalikan kepada argumentasi masing-masing (Amina Wadud-mufasir klasik),

${ }^{20}$ HR. Muslim nomor 1691. 
maka semua memiliki kekhasan tersendiri. Untuk itu, penafsiran Amina Wadud akan penulis bandingkan dengan pendapat para ulama klasik.

Al-Zamakshari, menjelaskan bahwa penafsiran kata nafs wāhidah sebagai berikut:

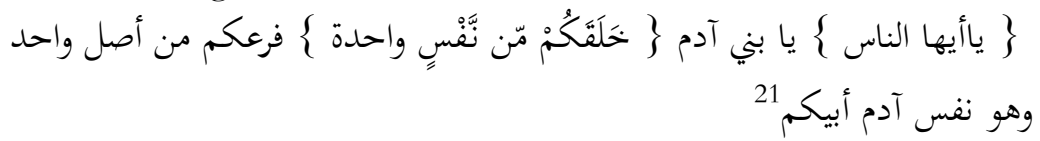

Itu artinya memang Zamakhshari benar-benar menafsirkan kata nafs wähidah sebagai Adam. Namun yang menjadi penting adalah penafsiran ini bukan hanya pendapat Zamakhshari saja, al-Mawardi ${ }^{22}$, Ibnu Abbās ${ }^{23}$, bahkan alTabari mengutip tujuh hadis yang menyatakan bahwa tafsir kata tersebut sama, yakni Adam, ${ }^{24}$ apalagi hal itu juga masih diperkuat oleh mufasir lain. ${ }^{25}$

Untuk menghukumi, apakah tafsir Amina Wadud benar atau salah, hingga saat ini belum ada bukti empiris yang membenarkan pebndapat tersebut, apakah manusia diciptakan dari Adam, atau sebaliknya?. Untuk itu, hemat penulis selama ini yang diperdebatkan adalah masalah yang belum bisa dibuktikan dan hanya sebatas keyakinan masing-masing dan jika dilihat kekuatan argumentasi, maka penulis lebih condong

21 Abū al-Qāsim Mạ̣mūd bin 'Amr bin Aḥmādal-Zamakhshari, al-Kashshāf. alMaktabah al-Shāmilah al-Iṣdār Thāni, QS. 4: 1.

22 Abū al-Ḥasan 'Ali bin Muḥammad bin Muḥammad bin Ḥabib al-Baṣri al-Māowardi, al-Nukat wa al- 'Uyūn. al-Maktabah al-Shāmilah al-Ișdār Thāni, QS. 4: 1.

${ }^{23}$ Yunsabu ilā al-Ṣahābah 'Abd Allāh ibn 'Abbās, Tanwìr al-Miqbās min Tafsìr Ibn Abbās. al-Maktabah al-Shāmilah al-Iṣdār Thāni, QS. 4: 1.

${ }^{24}$ Abū Ja'fär Muḥammad bin Jarìr bin Yazìd bin Ghālib al-Amūli al-Ṭabari, Jämio' alBayān fì Ta'wīl al-Qur'ān. Mu'assasah al-Risālah, 2000. QS. 4:1.

${ }_{25}$ Misalnya al-Qushairi, Tafsìr al-Qushairi, al-Khāzin, Lubāb al-Ta'wil fi Ma'ani al-Tanzìl, bahkan mufsir yang saat ini (2013) masih diberikan umur panjang oleh Allah, Wahabah al-Zuhaili dengan dua karya tafsirnya Tafsir al-Munir fi al-Aqidah wa al-Sharì'ah wa al-Minhäj dan Tafsir al-Wasit. 
kepada ulama klasik yang bersandar pada hadis, dan jika mengingkarinya, maka sama juga mengingkari hadis.

d. Untuk masalah wanita menjadi imam shalat sekaligus imam sejauh yang penulis ketahui - tidak ada sepanjang sejarah Islam yang berani melakukan hal itu, meskipun diakui, bahwa dalam Islam banyak sekte atau aliran, baik fikih, teologi maupun sekte yang lain. yang menjadi pertimbangan dalam masalah ini adalah urusan ibadah. Ibadah adalah mengajarkan kita untuk konsentrasi dan fokus kepada Tuhan, bahwa kita sedang menghadap Zat Yang Maha Tinggi, Maha Agung, oleh sebab itu, kita hendaknya konsentrasi dan meyadari bahwa kita sedang menghadap-Nya. bayangkan jika yang ada di depan para lelaki itu adalah wanita? Bayangkan jika imam shalat Jum'at adalah Julia Peres? Bagaimana jika ada sebuah pengumuman 'Para hadirn jamaah shalat Jum'at yang dimuliakan Allah, hari ini Jum'atan kita libur, karena sang Imam sedang haid'? di arena olah raga saja laki-laki dan wanita dibedakan, sebut saja tinju, sepak bola, gulat, karate dan sebagainya dibedakan, mengapa Amina Wadud tersinggung dalam masalah ibadah?.

e. Sejarah wanita di Barat

Perlu diketahui bahwa, hak-hak wanita dalam Islam lebih terjamin dibanding hak-hak wanita diluar Islam. Sebut saja misalnya dalam tradisi Yunani, kaum wanita bagi kalangan bangsawan disekap dalam kamar. Sementara itu, bagi kalangan rakyat jelata, kaum wanita diperjual belikan bagaikan barang dagangan. Selain itu, mereka juga tidak memiliki hak seperti mendapatkan waris, kepemilikan harta, dan bahkan tidak sedikitpun ikut andil dalam urusan keluarga, karena hal itu adalah urusan lelaki.

Pada saat kemuajuan Yunani, kaum wanita lebih mengenaskan lagi, mereka dijadikan suatu pemuas seks ditempat-tempat ramai, hal ini dapat dibuktikan dengan 
peninggalan sejarah berupa patung-patung telanjang yang berada di Eropa. ${ }^{26}$

Pada peradaban Hindu-Cina, perlakuan terhadap wanita lebih kejam lagi, yakni jika sang suami meninggal dunia, maka sang istri tersebut harus mati saat itu juga, yakni harus dibakar hidup-hidup. Yang labih parah lagi, kenyataan ini baru berahir pada abad ke-17. Wanita dalam traidsi Hindu juga sangat tidak terhormat, yakni para petuah mereka mengatakan 'racun, ular dan api tidak lebih jahat dari wanita.'

Dalam ajaran Yahudi juga demikian, wanita dinggap sebagai sumber laknat yang menyebabkan Adam terusir dari surga. Nasrani juga tidak boleh dilupakan dalam memperlakukan wanita, pada abad ke-5 Masehi, diadakan konsfrensi dengan pertanyaan, apakah wanita itu memiliki ruh atau tidak? Dan ahirnya berkesimpulan bahwa wanita itu tidak memiliki ruh suci. Di abad ke-6 juga demikian, dikalangan Kristen juga mempertanyakan eksistensi wanita, yakni apakah wanita itu manusia atau bukan, dan konsili tersbut memutuskan bahwa wanita itu adalah manusia yang diciptakan semata-mata untuk melayani laki-laki. Bahkan hingga tahun 1805, perundang-undangan Inggris mengakui hak suami untuk menjual istrinya, hingga tahun 1882-pun, wanita Inggris belum memiliki hak kepemilikan harta dan hak untuk menuntut kepengadilan. ${ }^{27}$

Gambaran kelam tentang wanita memang mewarnai dari beberapa dekade dalam sejarah Barat, terutama pada abad pertengahan. Adian Husaini menggambarkan betapa kejamnya Barat terhadap wanita. Ia mengutip dari buku yang ditulis oleh Robert Held berjudul Inquisition yang menampilkan foto-foto penyiksaan yang dilakukan oleh para tokoh gereja yang dengan 50 jenis alat penyiksaan, seperti tempat pembakaran hiduphidup, gergaji pembelah tubuh, alat pengebor vagina dan alat-

${ }^{26}$ M. Quraish Shihab, Tafsir Maudlu'i Atas Pelbagai Problematika Umat. Bandung, Mizan, 1996, 294.

${ }^{27}$ Ibid, 294-296. 
alat mengerikan lainnya. Ironisnya $85 \%$ dari orang yang disiksa tersbut adalah wanita. Antara tahun 1450-1800, diperkirakan ada dua sampai empat juta wanita dibakar hidup-hidup. ${ }^{28}$

Itulah gamabaran perlakuan peradaban diluar Islam dari beberapa sudut, maka wajar apabila Barat terjebak dalam titik yang ekstrim yang mana pada awalnya mereka benarbenar tidak menghargai wanita dan kini Barat membebaskan wanita dengan kebablasan. Oleh sebab itu, tidak adil jika hanya menyalahkan Islam dari satu sisi, sementara tidak tidak memuat perjalanan wanita diluar Islam.

Yang menarik adalah ungkapan Adian Husaini dalam masalah hermeneutika "Aturan Tuhan sudah tidak berlaku lagi, dan bahkan dapat dikatakan menuhankan manusia dan memanusiakan Tuhan." 29 Dr. Shamsudin Arif juga menyatakan "Orang yang mengadopsi hermeneutika digambarkan sebagai isteri Aladin yang menukarkan lampu lamanya dengan lampu baru yang dijajakan oleh si tukang sihir. ${ }^{30}$

\section{G. Kesimpulan}

Amina Wadud Muhsin lahir di Amerika pada tahun 1952, ayahnya adalah seorang Kristiani yang taat. Pada saat remaja, Amina Wadud tertarik dengan Islam tentang konsep keadilan, sehingga pada usia ke-20 tahun, Amina Wadud Muhsin menyatakan mengikrarkan diri menjadi seorang Muslim dengan mengucapkan dua kalimat syahadat. Dan pada puncak karirnya ia berhasil memperoleh gelar profesor Islamic Studies.

Sedangkan gagasan yang menjadi ciri khas Amina Wadud Muhsin, yakni dia menitik beratkan urusan-ursuan tentang gender.

28 Adian Husaini, Hegemoni Kristen Barat dalam Studi Islam di Perguruan Tinggi. Jakarta: Gema Insani Press, 2006, 260.

29 Adian Husaini, Wajah Peradaban Barat: Dari Hegemoni Kristen ke Dominasi Sekuler Liberal. Jakarta: Gema Insani Press, 2005, 1.

${ }^{30}$ Husaini, Wajah .... 333. 
Pembela wanita dari beberapa aspek, baik dalam ranah keluarga, publik, kepemimpinan, atau bahkan dalam memimpin shalat jum'at.

Prior text, adalah konsep yang dibangun oleh Amina Wadud bahwa apa yang dibaca oleh orang-orang saat ini adalah hasil dari buah pemikiran orang yang terdahulu, dan karena orang-orang tersebut didominasi oleh kaum pria, maka wajar apabila gagasan serta ide yang dia bangun memiliki bias gender. Teks-teks klasik yang menjelaskan posisi wanita itu dianggap tidak tepat karena dalam kenyataannya, dalam memaknai ayat tentang penciptaan perempuan, nushuг, kepmimpinan wanita yakni ratu Saba' dianggap sebelah mata oleh para mufasir klasik. Selain itu, apa yang dilakukan oleh Amina Wadud tentang menjadi imam shalat ini dianggap sah atas nama Islam, karena adanya hadis tentang Ummu Waraqah yang diperintahkan oleh Nabi untuk menjadi imam shalat.

Sebagai mujtahid gender, ia menawarkan hermeneutika tauhid, yang mana hal tersebut didasarkan kepada al-Qur'an yang menyatakan dengan tegas bahwa dihadapan Allah semua sama, ukurannya bukan kelamin, akan tetapi takwa. Bagi orang yang telah beriman akan ke-Esaan Allah, maka ia memiliki kesempatan yang sama untuk menjadi seorang pemimpin, baik urusan umum maupun urusan ibadah. 
Spiritualis, vol. 4, no. 1, Maret 2018|48

\section{DAFTAR PUSTAKA}

Deedat, Ahmad. The Choice. Jakarta: Pustaka al-Kautsar, 1999.

Ghafur, Saiful Anwar. Profil Para Mufasir al-Qur'an, Yogyakarta: Pustaka Insan Madani, 2008.

Handono, Irena. Islam Dibujat, Kudus: Bima Rodheta, 2004.

Husaini, Adian. Hegemoni Kristen-Barat dalam Studi Islam di Perguruan Tinggi, Jakarta: Gema Insani Press, 2006.

-------, Wajah Peradaban Barat: Dari Hegemoni Kristen ke Dominasi Sekuler Liberal, Jakarta: Gema Insani Press, 2005

Ibn 'Abbās, Yunsabu ilā al-Ṣahābah 'Abd Allāh. Tanwìr al-Miqbās min Tafsìi Ibn Abbās, al-Maktabah al-Shāmilah al-Iṣdār Thāni.

al-Khāzin, Lubāb al-Ta'wil fi Ma'ani al-Tañìil, al-Maktabah al-Shāmilah al-Iṣdār Thāni.

Lembaga Alkitab Indonesia, Perjanjian Baru, Mąmur dan Amsal (Jakarta: Lembaga Alkitab Indonesia, 2010.

Mustaqim, Abdul. Dinamika Sejarah Tafsir al-Qur'an: Studi Aliran-aliran Tafsir dari Periode Klasik, Pertengahan, hingga Modern-Kontemporer, Yogyakarta: Adab Press, 2012.

Māwardi (al), Abū Ḥasan Ali bin Muhammad bin Hạabib. al-Nukat wa al-Uyūn, al-Maktabah al-Shāmilah al-Ișdār Thāni.

Qadri, Hamid. Awan Gelap dalam Keimanan Kristen: Perjalanan Sejarah Kepercayaan Kristen, Pengarub Mitologi Kuna dan Filsafat, terj. Masyhur Abadi, Surabaya: Pustaka Da’i, 2004. 
Spiritualis, vol. 4, no. 1, Maret 2018|49

Samuel, Molyadi. Dokumen Kepalsuan Alkitab, Surabaya: Victory Press, 2002.

Syamsudin, Sahiron. Hemeneutika al-Qur'an dan Hadis, Sleman Yogyakarta: Elsaq Press, 2010.

Shihab, M. Quraish. Tafsir Maudlu'i Atas Pelbagai Problematika Umat, Bandung: Mizan, 2006.

al-Ṭabari, Abū Ja'far Muḥammad bin Jarìr bin Yazìd bin Ghālib alAmūli. Jämi' al-Bayān fī Ta'wīl al-Qur'an, Mu'assasah al-Risālah, 2000 .

al-Qushairi, Tafsì al-Qushairi, al-Maktabah al-Shāmilah al-Iṣdār Thāni.

W. Funk, Robert. Roy W. Hoover and The Jesus Seminar, The Five Gospels. What Did Jesus Really Say? Harper San Fransisco: 1997.

al-Zamakhshari, Abū al-Qāsim Mạ̣mūd bin 'Amr bin Aḥmād. alKashshāf, al-Maktabah al-Shāmilah al-Iṣdār Thāni.

al-Zuhaili, Wahabah Muștafa. Tafsir al-Munir fi al-Aqidah wa al-Sharìah wa al-Manbaj al-Maktabah al-Shāmilah al-Iṣdār Thāni.

--------, Tafsir al-Wasịt. al-Maktabah al-Shāmilah al-Iṣdār Thāni. 